\title{
The Use of Enamel Matrix Derivative in Combination with a Synthetic Bone Graft in the Treatment of Periodontitis: A Case Report
}

\author{
M Siaili, D Chatzopoulou and DG Gillam* \\ Barts and the London School of Medicine and Dentistry QMUL, United Kingdom
}

Submission: April 05, 2019; Published: April 17, 2019

*Corresponding author: Dr David Gillam, Oral Bioengineering, Institute of Dentistry, Barts and the London School of Medicine and Dentistry QMUL, Turner Street, London E1 2AD, London, United Kingdom

\section{Abstract}

This case report describes the surgical management of a patient with a diagnosis of Generalized Aggressive Periodontitis using a mixed regenerative material which combined an enamel matrix derivative with an alloplastic bone substitute in both infra bony defects and furcation areas. The importance of an extensive oral hygiene regime following the surgical procedure as well as the patient's ability to maintain an optimal plaque control is also key to the successful management of the patient's condition.

Keywords: Surgical technique; Infra bony and furcation defects; Enamel matrix derivative; Bone ceramic; Case report; Patient compliance; Synthetic bone graft; Periodontal disease

Abbreviations: GTR: Guided Tissue Regeneration; BMP: Bone Morphogenetic Proteins; EMD: Enamel Matrix Proteins; PPD: Probing Pocket Depth

\section{Introduction}

It has been recognised that periodontal disease in susceptible individuals may lead to the gradual loss of the tooth supportive apparatus. Therefore, the objective of periodontal treatment is not only the arrestment of the progression of periodontitis but additionally to aid in the reconstruction of lost structures such as bone, cementum and periodontal ligament using regenerative procedures and techniques such as Guided tissue regeneration (GTR) with and without the use of bone grafting materials [1,2]. Over the last three decades there has been a major development of novel materials for the treatment of periodontal disease, particularly regarding the treatment of infra bony defects. For example, stem cells, conductive scaffolds, platelet-rich plasma, Bone Morphogenetic Proteins (BMPs), cell binding peptides, fibroblast growth factors and Enamel matrix proteins (EMD) as well as bone replacement products such as autograft, xenograft, allograft and alloplastic grafts [2]. Several investigators have, however reported on the efficacy of EMD compared to the other biomaterials in combination with regenerative procedures [3-6]. According to Fernandes et al. [6] there are considerable benefits in combining both EMD and a bone ceramic as there is potential to create a synergetic effect of both these materials.

\section{Aim}

The aim of this case report therefore was to describe a surgical procedure for the application of a mixed regenerative materi

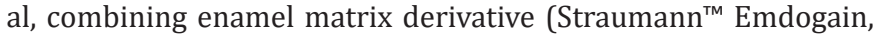
Straumann, Basel, Switzerland) and alloplastic bone substitute (hydroxyapatite and $\beta$ - tricalcium phosphate) (Straumann ${ }^{\mathrm{TM}}$ Bone Ceramic, Straumann, Basel, Switzerland), in intra bony defects and furcation involved areas located at upper posterior teeth.

\section{Materials and Methods}

A 26-year old, non-smoking Asian male with a diagnosis of Generalized Aggressive Periodontitis, presented to the postgraduate periodontal clinic in the Dental Hospital. The patient provided written informed consent for the proposed treatment and after the completion of two courses of non-surgical periodontal treatment with adjunctive systemic antibiotics (Doxycycline 100mg, s.i.d. for 21 days), surgical treatment of the infra bony defects and furcation defects of the affected sites was provided. The patient's compliance with self-performed plaque control was optimal throughout both non-surgical and surgical procedures as well with the post-surgical maintenance phase.

\section{Surgical procedure}

On the maxillary left first premolar the maximum probing pocket depth (PPD) was $7 \mathrm{~mm}$ on the mesial site with bleeding on probing. An angular bony defect was noted on the same site on a periapical radiograph (PA). On the maxillary left first molar the maximum PPD was $8 \mathrm{~mm}$ on the mesial and distal site, with a Mill- 


\section{Advances in Dentistry \& Oral Health}

er Class II involvement of all furcation and bleeding on probing. An angular bony defect was also noted mesially of the same tooth on a PA (Figures $1 \& 2$ ).

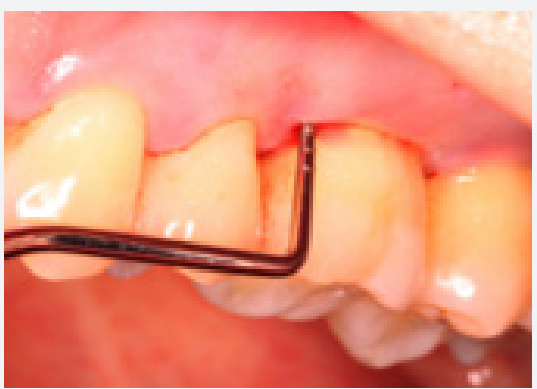

Figure 1: Periodontal probe measuring a pocket depth of up to $8 \mathrm{~mm}$.
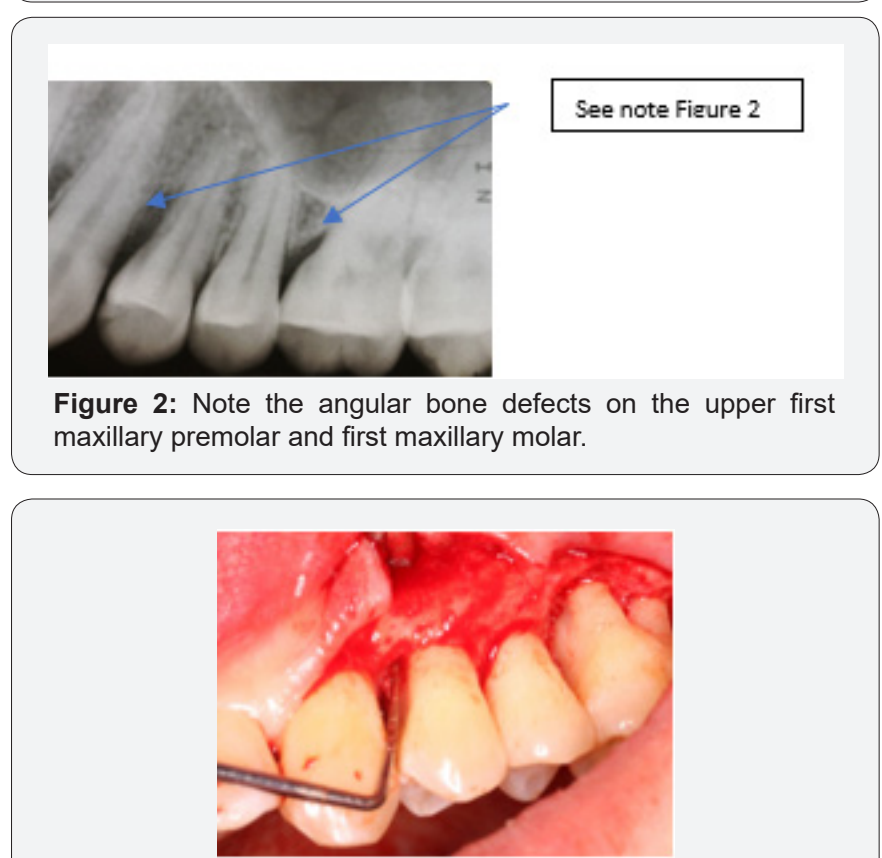

Figure 3: Reflected flap with a periodontal probe indicating a shallow 3-wall defect.

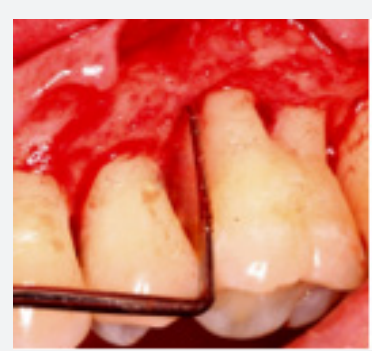

Figure 4: Reflected flap with a periodontal probe indicating a circumferential defect.

Full-thickness flaps were elevated, granulation tissue adherent to the bone was removed and the tooth surfaces were debrided thoroughly. After root conditioning with ETDA gel (Straumann PrefGel $^{\mathrm{TM}}$, Straumann, Basel, Switzerland), the 3-wall bony defect on the mesial site of the first premolar (Figure 3) and the circumferential defect around the first molar (Figure 4) were gently filled with the mixed material (Figures 5-7). The flaps were coronally advanced and secured with simple interrupted sutures (4.0 glucolide/lactide copolymer sutures $\left\{\right.$ Polysorb $^{\text {TM }}$ \}) (Figures 8 \& 9) and post-operative instructions were given to the patient (Patient was instructed to refrain from toothbrushing of the site for two weeks, to rinse with $0.12 \%$ chlorhexidine mouthwash \{Corsodyl GSK $®$ \} three times daily and to have a soft diet, avoiding any brushing or eating in the region of the surgical site.
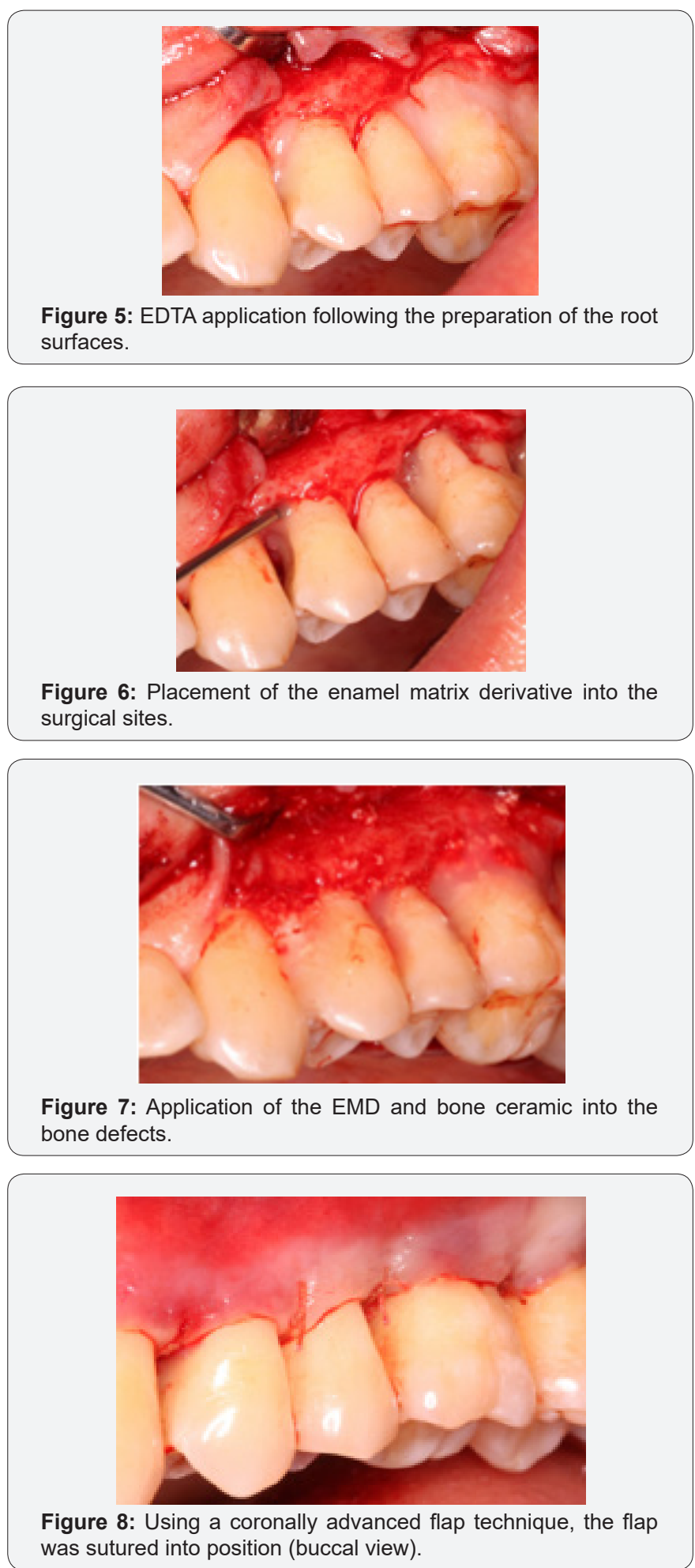


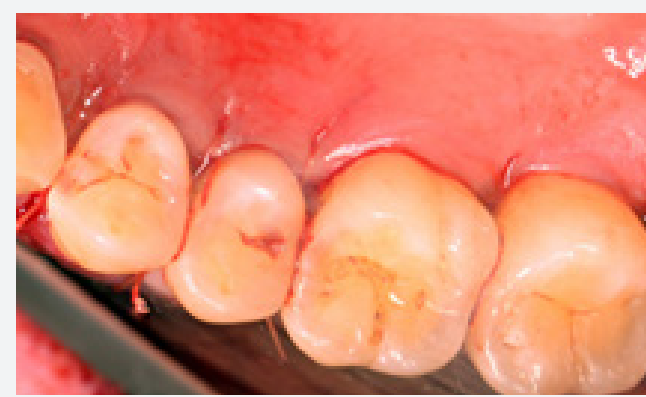

Figure 9: Using a coronally advanced flap technique, the flap was sutured into position (palatal view).

\section{Post-operative follow up}

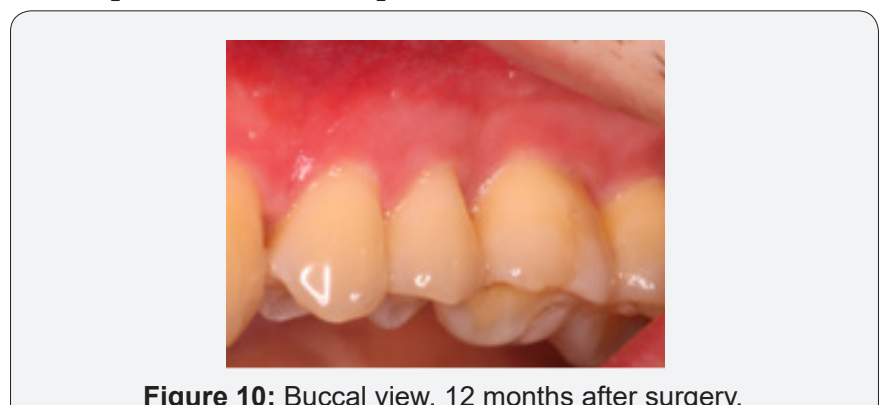

Figure 10: Buccal view, 12 months after surgery.

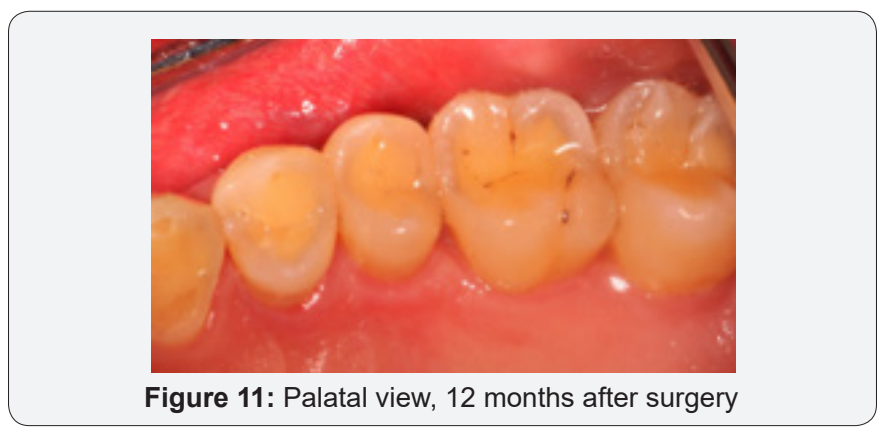

Following the placement of the regenerative materials in the intra bony defects, the patient was reviewed at 1, 4 and 12 months. Excellent healing of the soft tissues was evident with no signs of inflammation observed (Figures 10 \& 11) and probing depths did not exceed the accepted $3 \mathrm{~mm}$ pocket depth for healthy gingiva.

At the 12 months radiographic assessment evidence of bone fill of the defects was observed on the periapical radiograph (Figure 12a). A comparison of the baseline and 12-month post-surgical radiographs (Figure $12 \mathrm{a} \& 12 \mathrm{~b}$ ) would indicate that the

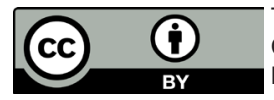

This work is licensed under Creative Commons Attribution 4.0 License DOI: 10.19080/ADOH.2019.10.555797 combination of an enamel matrix derivative and bone ceramic was successful in repairing the periodontal infra bony defects. Furthermore, the clinical measurements following the surgery were within the accepted range for healthy pocket depths and the excellent compliance of the patient in maintaining good oral hygiene was undoubtedly a factor in the successful management of this patient's periodontal condition.

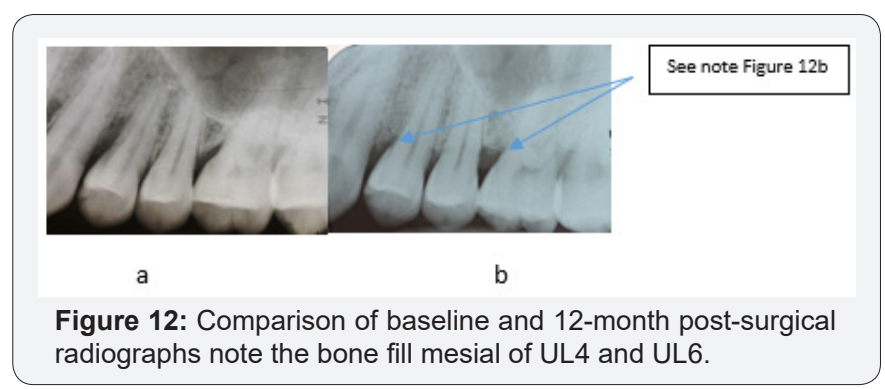

\section{Conclusion}

In cases of advanced periodontal destruction due to periodontitis, surgical reconstruction of specific sites can be achieved using Enamel matrix derivative and alloplastic bone substitutes which appear to be a promising combination for regeneration of periodontal tissues.

\section{References}

1. Needleman I, Tucker R, Giedrys-Leeper E, Worthington H (2005) Guided tissue regeneration for periodontal intrabony defects--a Cochrane Systematic Review. Periodontol 2000 37: 106-123.

2. Siaili M, Chatzopoulou D, Gillam DG (2018) An overview of periodontal regenerative procedures for the general dental practitioner. Saudi Dent J 30(1): 26-37.

3. Trombelli L, Farina R (2008) Clinical outcomes with bioactive agents alone or in combination with grafting or guided tissue regeneration. J Clin Periodontol 35(8 Suppl):117-135.

4. Esposito M, Coulthard P, Thomsen P, Worthington HV (2003) Enamel matrix derivative for periodontal tissue regeneration in infrabony defects: a Cochrane systematic review 68(8): 834-844.

5. Esposito M, Grusovin MG, Papanikolaou, N, Coulthard P, Worthington HV (2009) Enamel matrix derivative (Emdogain) for periodontal tissue regeneration in intrabony defects. A Cochrane systematic review. Int J Oral Implantol 2(4): 247-266.

6. Fernandes PG, Zotarelli Filho IJ, Apolinário Vieira GH, Novaes Jr AB, Scombatti de Souza SL, et al. (2015) Periodontal Intrabony Defects and the Treatment with Enamel Matrix Derivative and a Synthetic Bone Substitute in Humans: A Clinical and Radiographic Case. J Interdiscipl Med Dent Sci 3(4): 185.

\begin{tabular}{|l|}
\hline \multicolumn{1}{|c|}{ Your next submission with Juniper Publishers } \\
will reach you the below assets \\
- Quality Editorial service \\
- Swift Peer Review \\
- Reprints availability \\
- E-prints Service \\
- Manuscript Podcast for convenient understanding \\
- Global attainment for your research \\
- Manuscript accessibility in different formats \\
( Pdf, E-pub, Full Text, Audio) \\
- Unceasing customer service \\
Track the below URL for one-step submission \\
https://juniperpublishers.com/online-submission.php \\
\hline
\end{tabular}

